\title{
生理活性タンパク質による治療最適化を指向した遺伝子・細胞製剤の開発
}

\author{
櫻 井文 教, ${ }^{*, a, b}$ 西川 元 也 ${ }^{c}$
}

\section{Development of Cellular and Gene Therapy Products for Bioacitve Protein-based Therapy}

\author{
Fuminori SAKURAI ${ }^{*, a, b}$ and Makiya NISHIKAWA ${ }^{c}$ \\ ${ }^{a}$ Department of Biochemistry and Molecular Biology, Graduate School of Pharmaceutical Sciences, Osaka \\ University, 1-6 Yamadaoka, Suita, Osaka 565-0871, Japan, ${ }^{b}$ Laboratory of Stem Cell Regulation, \\ National Institute of Biomedical Innovation, 7-6-8 Saito-Asagi, Ibaragi, Osaka 567-0085, \\ Japan, and ${ }^{~}$ Department of Biopharmaceutics and Drug Metabolism, Graduate \\ School of Pharmaceutical Sciences, Kyoto University, 46-29 Yoshida \\ Shimo-adachi-cho, Sakyo-ku, Kyoto 606-8501, Japan
}

近年, 分子生物学の爆発的な進歩により疾患の原 因となる遺伝子が次々と明らかにされてきた。それ に伴い，疾患の原因となる遺伝子がコードするタン パク質を利用して疾患を治療しようとする先端的治 療が盛んに研究されている。その実現には目的の夕 ンパク質を「必要な時に, 必要な場所に, 必要な量」 でデリバリーする技術の開発が必要不可欠である.

これまでは主にタンパク質又はタンパク質誘導体を 投与するアプローチが検討されてきた。しかしなが ら最近では，こうした従来のアプローチに加えてタ ンパク質をコードした遺伝子を投与する「遺伝子治 療」と，治療用タンパク質を発現する細胞を投与す る「細胞治療」が近年大きな注目を集めている.夕 ンパク質若しくはタンパク質誘導体を投与する治療 法と比較し, 遺伝子治療・細胞治療においては, 克 服すべき多くの問題が存在することも事実である が，一方で夕ンパク質を投与する治療法では存在し ない様々な長所もある。例えば遺伝子治療において は，単回投与で長期間に渡りタンパク質を発現・供 給できること，またタンパク質の発現とともに免疫 応答を強く惹起することにより，治療効果を増強可 能なことが挙げられる。一方, 細胞治療において

${ }^{a}$ 大阪大学大学院薬学研究科分子生物学分野 ( ₹ 5650871 大阪府吹田市山田丘 1-6), b独立行政法人医薬基 盤研究所幹細胞制御プロジェクト（テ567-0085 大阪府 茨木市彩都あさぎ 7-6-8), $c$ 京都大学大学院薬学研究科 情報薬学分野（干606-8501 京都市左京区吉田下阿達町 46-29)

*e-mail: sakurai@phs.osaka-u.ac.jp

日本薬学会第 130 年会シンポジウム S19 序文
は，細胞自身が有する標的指向性を利用した標的組 織へのターゲティングの可能性や, 細胞機能を巧み に利用することでタンパク質を供給する以上の治療 効果を得ることも可能である.さらに近年では，様 々な研究分野での最新の知見を応用・融合すること で，遺伝子導入・発現技術及び遺伝子導入による細 胞制御技術は数年前と比較し格段の進歩を遂げてい る.こうした技術は単に遺伝子・細胞を体内に導入 してタンパク質を補給することに留まらず，幹細胞 の分化制御といつた新たなアプローチを創出すると ともに, 周辺領域へフィードバックすることにより 科学全体の進歩に多大な貢献をもたらしている．今 後, これらの革新的技術が臨床応用並びに創薬へと つながっていくことが期待される.

そこで本シンポジウムでは, 生理活性タンパク質 による治療の最適化を指向した遺伝子・細胞製剤の 開発に関して，遺伝子導入・発現ベクターや投与方 法, 細胞治療システムの作製に関して最新の知見を 発表して頂いた。 以下に本シンポジムのシンポジス トと講演タイトルを紹介する．1.「バブルリポソー ムと超音波技術を融合した筋組織への遺伝子導入シ ステムの開発」根岸洋一 (東京薬科大学), 2.「マ イクロ RNA による遺伝子発現制御システムを搭載 した組換えアデノウイルスの開発」櫻井文教（医薬 基盤研究所），3.「発現タンパク質の時空間制御に よる遺伝子治療効果の最適化」西川元也 (京都大学),

4.「ベクター産生型骨髄間質細胞を利用した遺伝子 治療」岡田尚巳（国立精神・神経センター)，5.「が ん細胞免疫療法の治療成績向上のための要素技術開 
発：樹状細胞体外大量増幅技術開発とセンダイウイ ルスによる免疫刺激療法」米満吉和（九州大学）, 6.「iPS 細胞への遺伝子導入を用いた分化誘導の最 適化」川端健二（医薬基盤研究所）。

最後に本シンポジムの開催並びに誌上シンポジウ ムの執筆・掲載にあたり，貴重な機会を与えて頂き
ました日本薬学会第 130 年会組織委員会・スタッフ の先生方並びに日本薬学会役員の先生方, そして今 回シンポジストとしてご参加頂きました先生方並び に関係者の皆様に，この場を借りて厚く御礼申し上 げます。 